\title{
Sustainable Supply Chain Management: Exploring the Role of Supply Chain Dynamic Capabilities in Determining Firm Performance
}

\author{
Elok Savitri Pusparini ${ }^{1}$ and Ratih Dyah Kusumastuti ${ }^{2}$ \\ ${ }^{1,2}$ Economics and Business Faculty, University of Indonesia, Depok, West Java, Indonesia, \\ 1'eloksp@ui.ac.id.
}

\begin{abstract}
Over the last decades, there is a growing body of research upon the theory and practice of sustainable supply chain management (SSCM). Although supply chain have long been viewed as a mean to enhance performance, strategic management scholars focusing more in marketing, logistics, and operations management, while relatively limited research has been conducted on the extent to which firms have integrate sustainability principles into the management of their supply chain. In the effort to posits new insights on why some firms outperform others, this study build on strategy theory, operations management theory, business ethics theory, and resource-dependence theory to examine the concept of stakeholder pressure, supply chain orientation, sustainable supply chain management, and supply chain dynamic capabilities upon their impact on firm performance.Four propositions has drawn from the literature review, opening further research venue to empirically test the research propositions. This study contributes to the emerging body of research by addressing the relationship between sustainable supply chain management and supply chain dynamic capabilitiesand through that the impact on firm performance. It is also attempt to contribute insights from the context of the developing countries which have some underlining differences with the developed countries espescially in the context of sustainability efforts. Finally, we present the conceptual model that ilustrates the possible relationship among the variables.
\end{abstract}

Keywords:Sustainable supply chain management, stakeholder pressure, supply chain orientation, supply chain dynamic capabilities, firm performance.

\section{Introduction}

Over the last deacades, a part of strategic management research has begun to examine the strategic supply chain management as the elaboration of a supply chain, not only merely as a means to get products where they need to be, but also as a tool to enhance key outcomes[1]; [2]; [3].Supply Chain Management (SCM)has been defined as "the management of upstream and 
downstream relationships with suppliers and customers to deliver superior value at less cost to the supply chain as a whole" [4]It is the answer of dynamic external condition that caused any industrial players take all kind of strategic actions in order to preservere their ability to cope with the changes.

Furthermore, the emerging issues such as environmental protection, corporate trasparency, responsible innovation, social responsibility, employee benefits and security concern, and green business strategy, have force operating corporations to swift their practices into environmentally friendly supply chains to reach harmony, not only with the society but with the nature as well. Integration of the sustainability concept into the core business functions in such away fall within the domain of supply chain management, such as procurement, supplier, logistics, operations, and knowledge management, has led to a critical-interdiciplinary area, that is sustainable supply chain management (SCM) [5]

The elaboration of ethics principles into strategic management body of knowledge can be found earlier in the Hosmer [6] seminal article which titled "strategic planning as if ethics mattered". Hosmer's profound thinking on the inclusion of more ethics research in the field of strategy as the moral obligations of management become part of several other components in the strategic planning process during the early development of Corporate Strategy as a field of Study [7]

However, research on the collaboration between strategic management theories and the sustainable supply chain management theories [8] are inconclusive, especially in determining how these combination may answer the challenge to provide sustainable performance as well as economic performance and social performance in a highly competitive, complex, and globalized context. As we all know, globalization of the market, sourcing, manufacturing, and distribution is growing, and customer are becoming more demanding, with the expectation upon customized products, and better customer service. Companies are urged with high competitive pressure, shorten product life cycles, high product variety, and high technological changes. As the result, supply chain have become highly complex and dynamic [9] However, the exploration of dynamic capabilities in the supply chain level up until now is remain underexplored. Research stream in dynamic capabilities still focusing more on building dynamic capabilities over the corporate level. While the competition currently is no longer lies between one single company to another, instead it already shifting into competition among one supply chain toward other supply chain. Academic reasearch lagging the current dynamics as well, especially in the context of emerging economy where the exploration regarding supply chain competition remain silent. Therefore, this conceptual study aimed to break this silence and bring the concept of supply chain dynamic capabilities into open discussion. This study contributes in overing hypothetical model that elaborates supply chain dynamic capabilities construct in determining firm overall performance, including economic, social, and environmental performances. Discussed also the role of stakeholder pressure upon sustainability and the extent of supply chain orientation as antecedent factors that urge focal firms to develop their strategic capabilities.

\section{Theoretical Foundation}

\section{a. Revisiting The Strategic Management Theory Literature}

Main stream research in strategic[10]; [11]; [12]; [13];[14]; [15] has focused on developing tools capable of prescribing a particular course of action for practitioners, deploying inductive 
logic to infer pronciples, theoretical claims, and other empirical evidence. As Porter [14]stated that "the fundamental basis of above-average performance in the long run is sustainable competitive advantage; eventhough a firm can have a myriad of strengths and weaknesses vis-a-vis its competitors, there are two basic types of competitive advantage a firm can posses: low cost or differentiation. The significance of any strength or weakness a firm possesses is ultimately a function of its impact on relative cost or differentiation" [14]

Porter's conceptualization on the low cost and differentiation as sources of above-average performance opening the debates on the nature of competitive advantage that appears to be deductive in nature and is clearly not the whole picture. As an alternative to Porter's framing on the competitive advantage, strategic scholars focusing more on internal organizational resources suggested the fundamental concept of resource-based view (RBV), with the attempt to replace Porter's generic strategies with generalized VRIN (valuable, rare, inimitable, and non-sustitutable) advantages [10]Hence, the premise VRIN advantages are sources of sustained competitive advantage makes the RBV a virtual tautology as well. RBV scholars hypothesize that (1) if a firm possesses and exploits resources and capabilities that are both valuable and rare, it will attain a competitive advantage, (2) if these resources and capabilities are also both inimitable and nonsubstitutable, the firm will sustain this advantage, and (3) the attainment of such advantages will enable the firm to improve its short-term and long-term performance [16]; [10], [10], [17]; [18].

Powell [19]challange the RBV by proposing the counterfactual condition of compeititve disadvantage, and suggests that the competitive advantage and competitive disadvantage are quite independent. In the condition where competitive advantage stems from inimitable, idiosyncratic resources, competitive disadvantage is not only non-existence of such resources, but failed to satisfy the minimum success requirements od strategic industry factors as well. In order to put the RBV's hypotheses to the test, most scholars have employed a 'resource heterogeneity approach', where a specific resource or capability is argued to be valuable, rare, inimitable, and nonsustitutable, then the amount of that resource or capability posessed by a firm is correlated with its competitive advantage or performance [20]

The results show that although a specific resource or capability may be found to exhibit a strong correlation with competitive advantage and/or performance in a particluar context, that resource or capability may simpy not fit with the enterprise-level startegies of all firms operating in that context. It might be more useful to the industries if the academic research may suggest on how to predetermine the resources and capabilities ought to be closely correlated with competitive advantage and/or performance, and identify which characteristics of resources and capabilities are related to these ends [21]

The capabilities refer to a firm's capacity to deploy resources, usually in combination, using organizational processes, to effect the desire end; they are information-based, tangible or intangible process that are firm specific and are developed over time through complex interactions among the firm's resources; they can be abstractly be thought of as 'intermediate goods' generated by the firm to provide enhanced productivity of its resources, as well as strategic flexibility and protection for its final product or service [16]. Based on thee definition, Teece et al. [18] have argued that capabilities cannot easily be bought, instead, they must be built. Likewise, Amit and Schoemaker [16]contend that some of the firm's resources, but especially its capabilities, may be subject to market failure. If capabilities must be built, not bought, then the manager's role may be more nearly analogues to an architect than to a stock-picker trying to beat the market [22] 
Capabilities are developed in the context of organizational resource allocation which is embedded in idiosyncratic social structures, also can be seen as distinct behavioral patterns, which are complex in nature, involving both formal and informal processes [23] Capabilities represent a repository of historical experiences and organizatioal learning [24]In case of superior performance and unique historical development, capabilities are assumed to build the foundation for sustainable competitive advantage. Accordingly, organizational capabilities can be build in differenct fields and on different levels of organizational activity, for instance at departemental, divisional, or corporate level, and it also addressed complex processes across the organizationa such as product development, customer relationship, and supply chain management [25].

\section{b. Strategic Supply Chain Management}

The nature of competition has increasingly moving toward 'supply chian versus supply chain' struggles, since it serves as one way that firms manage reoccurring purchases, also referred as supply chain management (SCM), which covers the integration and management of supply chain organizations and activites through cooperative interorganizational relationships, effective business process, and high level of information sharing [26]. Supply chains are value-adding relations of partially discrete, yet inter-reliant, units that cooperatively transform raw materials into finished products through sequential, parallel, and/or netowork structures [27]Supply chains are also defined as groups of organizations that collectively process raw materials into finished goods [3] where such collaborative relationships are garnered increased attention in management research over the last several years [28]Overall, the implementation of suppy chain management can increase communication and cooperation among firms, and both parties may gain benefits such as decreased costs through reduced inventory and shorter order times, improved quality through better product design, and enhanced innovation through more diverse design process inputs [26] These current states are relatively new. Historically, the strategic management field has not devoted much empirical attention to supply chains, while related disciplines such as marketing and operations management have long emphasized the performance implications of operational activities.

In these era, organizational capabilities are highly valued attributes of firms; organizations want to be perceived as possessing salient capabilities. The competent and capable organization has become new ideal. Organization invests in their current capability set and build their strategies upon those capabilities [3] Supply chain capability is thus crucial, as Morash [29] stated that supply chain capability is the building block for supply chain strategy and a source of competitive advantage for firm success. Morash also indicated that different capabilities support different value disciplines, which are value discipline is demand-oriented logistics capability and value discipline is supply-oriented logistics capabilities.

The concept also explained by Lynch et al. [30]that devided supply chain capability into supply-driven process capabilities and demand-driven value-added capabilities. Supply-driven process capability involves a stream line and standardized supply chain business process for analyzing extensive or intensive distribution to create methods for delivering products and services efficiently and for reducing total distribution costst. While demand-driven value-added capabilities meet customer demand for special products or customized services, which are designed to create added customer value and to maximize customer satisfaction and continuos improvement. 


\section{c. Sustainable Supply Chain Management}

World Commission on Environment and Development [31]define sustainable development as the development that meets the needs of the present without compromising the ability of future generations to meet their needs. It is at the center of the sustainability conceptualization to interrelated the relationship among the economic, environmental, and social dimensions [5]Over the last decade, as van Marrewijk [32] explains, the three pilar of sustainability has been traslated into a corporate context by many author, leading to different definitions regarding corporate sustainability. Van Marrewijk [32]also points to the application of the concept of corporate sustainability to supply chain issues as particularly complex and challenging.

Increasing concern over the environmental impacts of firms' activities opened the extension of supply chains to include by-products and to consider the entire lifecycle of a product, increase the environmental decision making tools and green supply chain practices positively affect corporate and environmental performance [33]on the other side, focusing significantly only on environmental parameters may be counterproductive to improving the triple bottom line of the corporate performance [34]

While in the micro-economic, sustainable supply chain management has grown, resulting the elaboration of the three pillars (economic, sustainable, and social performance) of sustainability with core business practices, such as procurement, logistics, knowledge management, marketing, and operations. Sustainable supply chain management is the strategic and trasparent integration and achievement of an organization's social, environmental, and economic objectives in the systemic coordination of key interorganizational business processes for improving the long-term economic, social, and environmental performance of the individual organization and its supply chains [35]As Parmigiani et al. [36]suggest that the objective can be achieved by developing specific relational capabilities that enable the focal organization to design incentive mechanisms, improving upstream social and environmental conditions. While Wolf [37] has try to relate the sustainable supply chain management with stakeholder pressure and corporate environmental performance, and be able to present the reliability of the relationship among those particular aspects. Corporate tends to listen to the voice of their stakeholders to adopt and implement the sustainable supply chain management, and gained positive environmental performance as the results.

Almost an era before, Banerjee [38]suggest that a proactive sustainable supply chain management strategies as an important objective to an organization. In the proactive approach, an organization understands its dependence upon the long-term sustainability of its resource supply. It also recognizes the importance of promoting social welfare and environmental protection in the supply chain, to ensure long-term access to those resources. As Wolf [37]explains that an organization may seek to maintain the sustainability supply chain management in order to resolves some elements of a resource dependence problem. An organization may put extra efforts to increase the sustainability of its suppliers to ensure that the suppliers will be capable of delivering products over a long period of time. It also known as a proactive approach to sustainable supply chain management.

\section{d. Extent of A Supply Chain Orientation}

Taking the RBV insights toward intangibility, this current study focus on the supply chain orientation that involves internal firm members to understand what is it do their supply chain 
partners' needs, wants, and expectations. In order to measure the intangibility conceptualization, Hult, Ketchen, Nichols, [1] examined the role of an intangible "positional advantage" in shaping performance among multinational firms. Following Hult et al. [39]this study examines six potential first-order indicators of Supply Chain Orientation, which are: customer orientation, competitor orientation, value-chain coordination, supplier orientation, logistics orientation, and operations orientations.

Customer Orientation, competitor orientation, and Value-Chain Coordination are drawn from the research on Market Orientation [40]in the field of strategic marketing and management literatures. A customer orientation is viewed as the suffiecient understanding of a firm's target customers to be able to create superior value for them continuosly. A competitor orientation refers to understanding the short-term strengths and weaknesses of current rivals as well as the long-term capabilities of key current rivals and potential future new entrants. Value-chain coordination refers to the integrated use of resources at each sequential step of the chain as well as between functional areas, and facilitates the effectiveness of product and process flows within and across firms [13]

The next three indicators are taken from the operations management literature and supply management, including purchasing, procurement, and sourcing. A supplier orientation refers to the processes that enable the progress of value from raw material to final disposition.[41]; [41] Logistics management is the foundation of logistics orientation that involves planning, implementation, and controlling the efficient and effective flow and storage of goods, services, and informations from the point of origin to consumption in order to meet customers' [41];[39] And finally, operations orientation, refers to the design, operation, and desire for improvement of the production system that creates the firm's primary products, services, and accompanying information [41]

\section{e. Stakeholder Pressures}

Stakeholder theory is concerned with the nature of the relationship between the firm and its stakeholders. Following Freeman's [42]stakeholders are defined as " any group or individual who can affect or is affected by the achievement of the organization's objectives". Firms are posited to pay attention to stakeholder influence for normative, instrumental, and descriptive reasons [43]Normative explications of stakeholder theory move firm-stakeholder relations into an ethical realm, proposing that managers should consider the interests of those who have stakes in the organization. In this view, stakeholders have a legitimate interest in the firm's processes or products and these interests have intrinsic value [44]

Therefore, this stream of literature prescribes that managers have a moral obligation with) .[42], [44] Instrumental stakeholder theories predict firm behavior on means-ends reasoning, whereby the firm pursues its interests through managing relationships with stakeholders [45]The instrumental orientation sees firms as addressing the interests of stakeholders who are perceived to have influence. For example, Frooman [46]suggests the existence of four types of stakeholder influence and four types of resource relationship. The overall conclusion of this body of work is that managing stakeholders' interests will maximize the firm's performance [47]Finally, the descriptive tradition has focused on characterizing the actual actions of firms and stakeholder groups as they interact.

Managing pressures from stakeholders, potentially, increase firms's good relations with its various stakeholders, and thus, can be a valuable resource that may lead to performance advantages for the firm [48] employees will work harder to enhance the firm's effectiveness [49]); customers will increase their demand or pay premium prices for the firm's products [50]suppliers 
will be more willing to engage in knowledge sharing with the firm [51]; and local communities may provide favorable terms for the use of local infrastructure [52]Wolf (2014) explains that at the level of the supply chain, the role of impact external stakeholder could give to the firm is more complex, as previously explain by Zhu and Sakis [53]that coercive pressures from customers, competitors, and governments force the focal firm to the develop higher innovative solutions that generated from a stronger sustainable supply chain management. Empirical support also given by Sarkis et al. [53]that find a direct and positive relationship among stakeholder pressure and sustainable supply chain management. However, although the development of relationship pattern between stakeholder pressures and sustainable supply chain management have been incresed over the last years, it is much still can be done toward better understanding upon the role of stakeholder pressure.

\section{f. Supply Chain Dynamic Capabilities}

A sustainable supply chain management is based on the combination of sustainable theory and supply chain management [8]At the same time, globalization and digitization attach more challenges to modern supply chain management in terms of complexity and dynamicity, and that requires higher level of dynamic capabilities in supply chain. The capabilities in creating new abilities is essentialy the dynamic ability of the enterprise. This study follows Teece et al. [18]in defining dynamic capabilities as the ability to integrate, build, and reconfigure internal and external competencies to address rapidly-changing environments. Dynamic capabilities is undoubtly an extension of the resource-based view of the firm that emphasize more on resource development and renewal [54]While Sirmon [55] explain that resources both tangible and intangibe are bundled to create capabilities. Dynamic capabilities then focusing on how to achieve a competitive advantage within the supply chain [56]

As a basic thinking, Helfat and Peteraf [57]stated that heterogeneity of capabilties and resources in a population of firms is one of the cornerstones of the RBV. According to RBV conceptualization, competitive heterogeneity itself shall give the organization to experience an enduring and systematic performance differences among its closer rivals [58]. In the industry where every player particularly have unique bundles of resources and capabilities and only some of these resources and capabilities may lead to sustained competitive advantages as they may have differential effects on actual performance [47], [57], [59].

To be the source of competitive advantage, a resource or capability must be valuable as in it can enable the firm to improve its relative market position, rare as in short supply or in terms of resource functionality, and isolated from immitation or substitution or it is too costly to replicate [57], [57], [58]. Since supply chain is a potential source of those characteristics, firms will differ in terms of their possession of resources and capabilities that may lead to sustained competitive advantage, as well as their differential utilization and effectiveness, firms will experience longterm performances that is different from their competing rivals as well [60]

In this context, Supply chain dynamic capability, building on dynamic capabilities theory, is the ability of adjusting supply chain, and is an emerging also popular concept in recent years and yet its essence is difficult to grasp [61] The adoption of dynamic capabilities in the supply chain field can be traced from the work of Beske [62] which proposed that supply chain dynamic capability was the desired ability of this complex system to deal with environmental change as well as internal complex relationships. Compares to supply chain capabilities, supply chain dynamic capabilities make organizations more flexible, and therefore can more easily and swiftly 
adapt to market trend and effectively tackle market volatility, and eventually enable the firm to achieve sustainable competitive advantage in its industry. Beske et al. [63] breaks supply chain dynamic capabilities into supply chain reconstruction, knowledge evaluation, co-evolvement, flexible supply chain control, and supply chain partner relationship development. While Cheng et al. [64] devided supply chain dynamic capabilities into integration one and cooperation one. The competitive advantage of a firm is not from one particular sub-capability, but from the combination of all sub-capabilities [63]

\section{g. Firm Performance}

A firm's success may not depend on a single set of factors nor resources [57]and organizational performance measurement should not rely on a single method or approach. As Barney and Arikan [59] and Crook et al., [27]determine that the performance effects of strategic resources highlight the need to understand how managers effectively utilize these resources [65]). As for most of the management initiatives, one of the inquiry that always attract the attention is to know whether there are competitive advantage and opportunities associated with environmental management [66]

Consider also Donaldson and Preston [43]critics on the lack of reliable indicators on the stakeholder management side of the relationship, how does the organization formulate its organizational purposes, why and for whose benefit does the company exist, what role do stakeholders play in achieving its purposes, and what does the impact of strategic response upon stakeholders pressures on firms' performance In the words of Freeman [42] "if organizations want to be effective, they will pay attention to all and only those relationship that can affect or be affected by the achievement of the organization's purposes."

Sustainable supply chain management become critical to organization's vulnerability upon pressures both from external and internal stakeholder groups. Through sustainable supply chain management, a firm may gain its dynamic capabilities in order to give a profound way to improve firm's environmental, social, and economic performance and through it upon it's supply chain .[35], [37] It is also a clear perspectives that this objective can only be achieved by developing specific relational capabilities that enable the focal firm to design incentive mechanisms by improving upstream social and environmental conditions [36]

\section{Propositions and Conceptual Model}

a. The Direct Effect of Stakeholder Pressure on Sustainable Supply Chain Management

As a central tenet, stakeholder theory posits that a firm's obligations are not only with its shareholders but also with multiple groups or individuals [43] Specifically, resource dependence theorists argue that "organizations are not self-contained or self-sufficient" and are dependent on their external environment for resources [67]. In fact, "it is dependence of firms on environmental actors (i.e., external stakeholders) for resources that gives those actors leverage over a firm" [46] and allows them to influence organizational outcomes [67]. The more dependent an organization is on a group, the greater the power of that group, and the greater its ability to influence organizational outcomes [68] .According to the cognitive approach, organizations are viewed as interpretive systems involved in scanning the environment for data, assigning meaning to that data, and enacting a response based on its [49], [69]. Managers' interpretations of stakeholders' pressures have important implications for the level of firm's competitive advantage [70]

Furhermore, according to the reactive model, the focal firm would only engage in sustainable supply chain management if there is pressure from stakeholders to do so [37]. Thus, the focal firm does not recognize that sustainable supply chain management shall not accordingly affect the 
achievement of strategic objectives. On the contrary, the focal firm would infer that the hogh costs of building up sustainable supply chain management capabilities [71] Following the resourcedependence theory, a firm would either be threatened by or perceive to be actively in a resource dependent relationship with one or more of its stakeholder groups [46], [67] and respond to the pressure by engaging the sustainable supply chain management. Thus, the following proposition can be drawn:

Proposition 1: Stakeholder pressure determines the extent to which a firm engages in sustainable supply chain management.

\section{b. The Direct Effect of Extent A Supply Chain Orientation on Sustainable Supply Chain Management}

Literature on sustainable supply chain management (SSCM) has enlarge its focus on social and environmental issues related to purchasing and supply, from diversity sourcing [72] to procurement policies ([72]to the implementation of codes of conduct and other managerial tools. Attempts have been made to generalize the component of sustainable supply chain across industries, creating concepts of logistics and purchasing social responsibility [72]Supply chain orientation based on the findings of Hult et al. [39]are no other serves as an organizational capability, especially in managing good relationships with partnerts in supply chains, logistics systems, and elevating the opportunities to gain a sustainable competitive advantage as resourcebased view suggested. A supply chain orientation will positively affect desired outcomes, and up to now are still open to be explored consider its complexity. It is a fruitfull idea to engage it with a concept such as sustainability which brings a greater good for all parties under supply chains commitments.

Sustainability-based policies and practices in specific industries have been analyzed [50] even in comparison with alternative supply chain models. Building on the resource-based view basic thinking, this study follows Wolf [37]posits that the supply chain orientation which consists of 6 dimensions thus become one of criteria in the effort to implement sustainable supply chain management. Then the following proposition may drawn:

Proposition 2: Supply Chain Orientation determines the extent to which a firm engages in sustainable supply chain management.

\section{c. The Direct Effect of Sustainable Supply Chain Management on Supply Chain Dynamic Capabilities}

Sustainable supply chain management (SSCM) according to Carter and Rogers ([73]is the strategic, transparent integration and achievement of an organization's social, environmental, and economic goals in the systematic coordination of key organizational business processes for improving the long term economis performance of the individual firm and its supply chain. It is also a key to develop further stage of firm's strategic capabilities, into something that is more dynamic state. As we can see, SSCM assures the ownership of more routine-based organizational capabilities.

In a changing world, firm's organizations shall prepare them selves to face the challenge of highly dynamic competitions, not only in its solitaire role, but more on supply chain versus supply chain. It is essential for the success of supply chain management to incorporate information exchange along the supply chain as well as fast reactions to changing environment, integrating relevant parties, crating a high level of networking including the whole supply chain, in order to 
avoid social and environmental problems and minimize the risks also related efforts for the purchasing companies [74] Sustainable supply chain management (SSCM) shall bring short term competitive advantage, which in turn would boost further development of dynamic capabiity [34] Research stream which combine SSCM with the dynamic capability might consider as rare, especially in empirical based [75]. Following Gimzauskiene et al. [55]who suggest that the supply chain dynamic capability makes organizations more flexible, and therefore can more easily and swiftly adapt to market trend and effectively tackle market volatility, and eventually enable the firm to achieve sustainable competitive advantage in its industry. Hence, this following proposition can be drawn:

Proposition 3: Sustainable supply chain management determines the extent to which a firm own the supply chain dynamic capabilities.

\section{d. The Direct Effect of Supply Chain Dynamic Capabilities on Firm Performance}

Over the ever changing environment, the abilities in supply chain need to be adjusted constantly. Supply chain can only fulfill the market demand if new abilities are created to improve long term sustainable efficiency [75] Upon the same industry, close competitors show differences in their competitive behavior. According to the resource-based view, the competitive heterogeneity is determined by the differences in each players' resources and capabilities that in turn affects their competitive advantage or disadvantage [76]These capabilities according to Day nown as organizational or strategic capabilities, spread around different functional areas, actively involve many different personalities whose came from different managerial levels, and serve multiple objectives. It also includes outside-in process that involves marketing capabilities and market sensing capabilities; inside-out processes that involves, and spanning processes new product/service development [16] It is the capabilities by which organizations' resources are acquired and deployed in ways that match the firm's market environment that explains interorganizational performance variance over time [17], [18], [22] involve complex coordinated patterns of skills and knowledge that, over time, become embedded as organizational routines [12] [51]found that knowledge sharing among supply chain can improve efficiency, while Chen et al. [64] suggest the importance of flexibility to buffer the negative impact from supply chain breakdown and to enhance firm performance.

Supply chain dynamic capability is a relatively new conceptualization of normative dynamic capability as Teece [18] noted earlier. Up to now, there is only limited research discussing how the supply chain dynamic capabilities affect firm performance [75]. In a time before, Caniato et al. [77] discuss the luxury industry and manage to find a positive impact of supply chain dynamic capabilities upon firm performance. While Cheng et al. [64] find that in a highly competitive market, dynamic capability become an excellent weapon in improving innovative performance and new product development of firms. Thus, it is strengthen the urgency to give more profound causalities between the role of supply chain dynamic capabilities on elevating firm performance. Thus, the following proposition may drawn:

Proposition 4: Supply chain dynamic capabilities strongly impact firm performance.

\section{Conclusion}

This study define 4 propositions that highly need to be tested in an empirical state. Further research shall explore the possibility to find some other causalities related to the construct that have been discussed above, with the additions of moderation and control variables. Theoretical 
state indicated the positive effect of stakehlder pressure, extent of supply chain orientation, toward sustainable supply chain management. The existence of sustainable supply chain management theoretically indicates high supply chain dynamic capabilities and in turn, hypothetically will increased firm performance.

This study contributesover the prediction of the relationship patterns between strategic management, business ethics, and supply chain management field of research. The introduction of supply chain dynamic capabilities into the framework also provides more theoretical insights upon the sustainability supply chain management research area. The combination of supply chain management contruct and supply chain dynamic capability remain limited in the context of emerging economies where the conceptualization of sustainability atempts as cost-added activites, short-term positive impact, and closely related to higher complexity in its implementation.

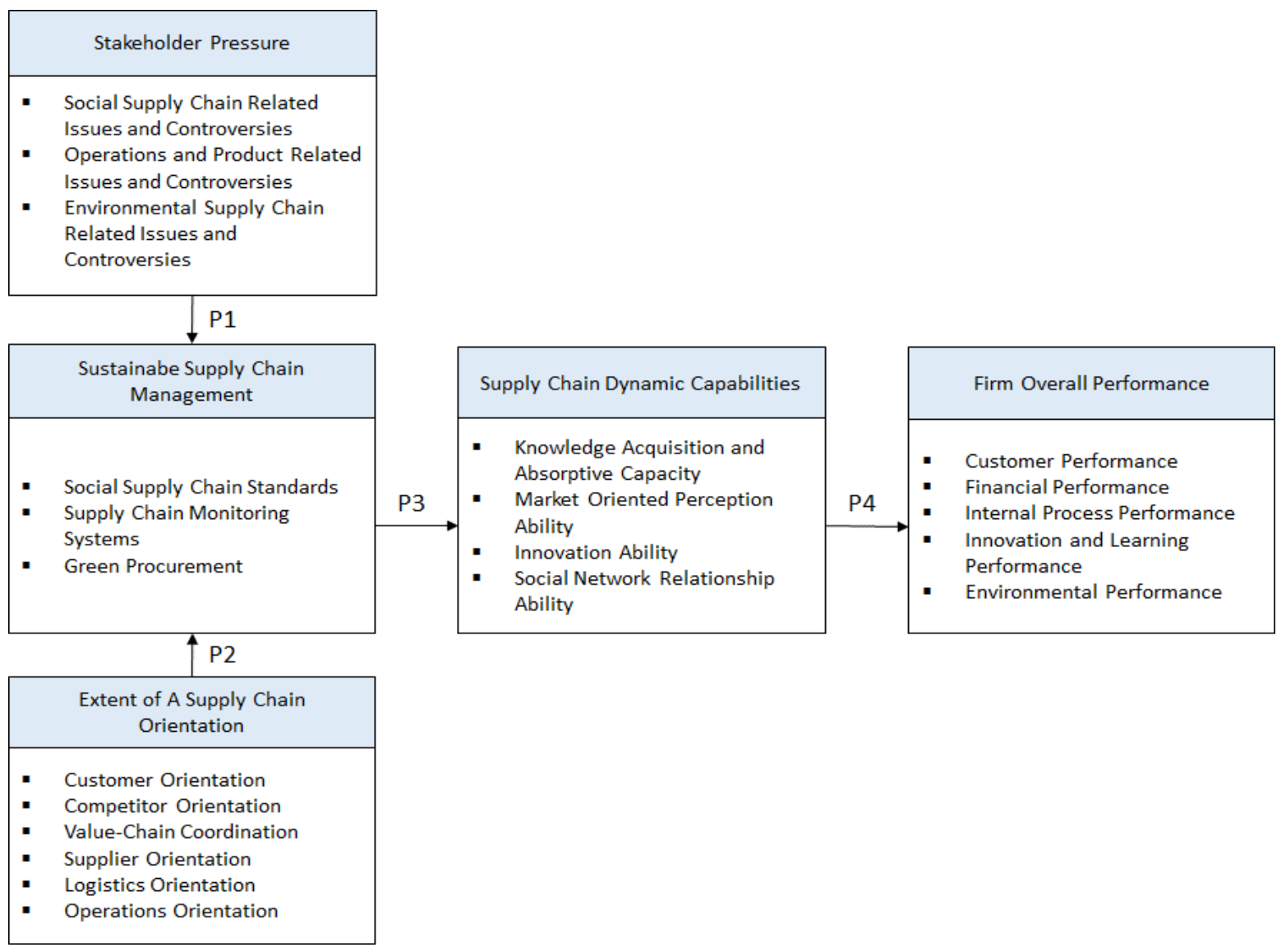

Fig. 1. Conceptual Model 


\section{REFERENCE}

[1] G. T. M. Hult, D. J. Ketchen, and E. L. Nichols, "An examintation of a culture of competitiveness and order fulfillment cycle time within supply chains," Academy of Management Journal, vol. 45, no. 3, pp. 577-586, 2002.

[2] G. T. M. Hult, D. J. Ketchen, and S. F. Slater, "Information processing, knowledge development, and strategic supply chain performance," Academy of Management Journal, vol. 47, no. 2, pp. 241-253, 2004.

[3] G. T. M. Hult, D. J. Ketchen, and M. Arrfelt, "Strategic supply chain management: Improving performance through a culture of competitiveness and knowledge development," Strategic Management Journal, vol. 28, no. 10, pp. 1035-1052, 2007.

[4] Z. Christoph, Dynamic Capabilities and The Emergence of Intra-Industry Differential Firm Performance: Insight From a Simulation Study, Department of Entrepreneurship INSEAD Boulevard de Constance 77305. Fontainebleau, France, 2000.

[5] O. Morali and C. Searcy, "A review of sustainable supply chain management practices in Canada," Journal of Business Ethics, vol. 117, no. 3, pp. 635-658, 2013.

[6] L. T. Hosmer, "Strategic planning as if ethics mattered," Strategic Management Journal, vol. 15 , no. 2, pp. 17-34, 1994.

[7] C. J. Robertson, "An analysis of 10 years of business ethics research in Strategic," Management Journal. Journal of Business Ethics, vol. 80, no. 4, pp. 745-753, 2008.

[8] P. Signori, D. J. Flint, and S. Golicic, "Toward sustainable supply chain orientation (SSCO): Mapping managerial perspectives," International Journal of Physical Distribution \& Logistics Management, vol. 45, no. 6, pp. 536-564, 2015.

[9] S. Kortmann, C. Gelhard, C. Zimmmermann, and F. T. Piller, "Linking strategic flexibility and operational efficiency: The mediating role of ambidextrous operational capabilities," Journal of Operations Management, vol. 32, no. 7-8, pp. 475-490, 2014.

[10] J. B. Barney, "Firm resources and sustained competitive advantage," Journal of Management, vol. 17, no. 1, pp. 99-120, 1991.

[11] C. M. Christensen and M. E. Raynor, The Innovator's Solution: Creating and Sustaining Successful Growth. Boston, MA: Harvard Business School Press, 2003.

[12] R. M. Grant, "The resource-based theory of competi tive advantage: implications for strategy formulation," California Management Review, vol. 33, no. 3, pp. 119-135, 1991.

[13] M. E. Porter, Competitive Strategy Techniques for Analyzing Industries and Competitors. New York: Free Press, 1980.

[14] M. E. Porter, advantage, Creating and sustaining superior performance. New York: Free Press, 1985.

[15] C. K. Prahalad and G. Hamel, "The core competence of the corporation," Harvard Business Review, vol. 68, no. 3, pp. 79-91, 1990.

[16] R. Amit and P. J. Schoemaker, "Strategic assets and organizational rent," Strategic Management Journal, vol. 14, no. 1, pp. 33-46, 1993.

[17] K. M. Eisenhardt and J. a Martin, "Dynamic Capabilities: What Are They?, Strategic," Management Journal, Strat. Mgmt. J, vol. 21, pp. 1105-1121, 2000.

[18] D. J. Teece, G. Pisano, and A. Shuen, "Dynamic Capabilities and Strategic Management," Strategic Management Journal, vol. 18, no. 7, pp. 509-533, Aug. 1997.

[19] T. C. Powell, "Complete advantage: logical and philosophical considerations," Strategic Management Journal, vol. 22, no. 9, pp. 875-888, 2001.

[20] S. L. Newbert, "Empirical research on the reseource-based view of the firm: An assessment and suggestions forvent future research," Strategic Management Journal, vol. 28, no. 2, pp. 121-146, 2007 
[21] S. L. Newbert, "Value, Rareness, Commpetitive Advantage, and Performance: A conceptual-level empirical investigation of the resource-based view of the firm," Strategic Management Journal, vol. 29, no. 7, pp. 745-768, 2008.

[22] R. Makadok, "Toward a Synthesis of the Resource-Based and Dynamic-Capability Views of Rent Creation," Strategic Management Journal, vol. 22, no. 5, pp. 387-401, 2001.

[23] S. G. Winter, "Understanding Dynamic Capabilities, Stragtegic Management," Journal, Strat. Mgmnt. J, vol. 24, pp. 991-995, 2003.

[24] S. G. Winter, "The satisficing principle in capability learning," Strategic Management Journal, Special Issue, vol. 21, no. 10-11, pp. 981-996, 2000.

[25] G. Schreyögg and M. Kliesch-Eber, "How Dynamic Can Organizational Capabilities Be? Towards a Dual-Process Model of Capability Dynamization," Strategic Management Journal, vol. 28, no. 9, pp. 913-933, 2007.

[26] R. Handfield and E. Nichols, Supply chain redesign. Upper Saddle River. New Jersey: Prentice Hall, 2002.

[27] T. R. Crook, L. Giunipero, T. H. Reus, R. Handfield, and S. R. William, "and outcome of supply chain effectiveness: An exploratory investigation," Journal of Managerial Issues, vol. 20, no. 2, pp. 161-177, 2008.

[28] M. Glisby and N. Holden, "Applying knowledge management concepts to the supply chain: How Danish firm achieved a remarkable break-through in Japan," Academy of Management Executive, vol. 19, no. 2, pp. 85-89, 2005.

[29] E. A. Morash, "Supply chain strategies, capabilities, and performance," Transportation Journal, vol. 41, no. 1, pp. 37-54, 2001.

[30] D. F. Lynch, S. B. Keller, and J. Ozmet, "The effects of logistics capabilities and strategy on firm performance," Journal of Business Logistics, vol. 21, no. 2, pp. 47-67, 2000.

[31] N. Banks, D. Hulme, M. Edwards, S. NGOs, and and, "Donors Revisited: Still Too Close for Comfort?," World Development, vol. 66, pp. 707-718, 2015.

[32] M. Van Marrewijk, "Concept and definitions of CSR and corporate sustainability: Between agency and communion," Journal of Business Ethics, vol. 44, no. 2-3, pp. 95-105, 2003.

[33] O. Michelsen, T. E. Fet, and A. Dahlsrud, "Eco-friendly extended supply chains: A case study of furniture production," Journal of Environmental Management, vol. 79, no. 3, pp. 290-297, 2006.

[34] J. Hall, S. Matos, and B. Silvestre, "Understanding why firms should invest in sustainable supply chains: a complexity approach," International Journal of Productions Res, vol. 50, no. 5, pp. 1332-1348, 2012.

[35] C. R. Carter and D. S. Rogers, "A framework of sustainable supply chain management: Moving toward new theory," International Journal of Physical Distribution \& Logistics Management, vol. 38, no. 5, pp. 360-387, 2008.

[36] A. Parmigiani, R. D. Klassen, and M. V. Russo, "Efficiency meets accountability: Performance implications of supply chain configuration, control, and capabilities," Journal of Operations Management, vol. 29, no. 3, pp. 212-223, 2011.

[37] J. Wolf, "The relationship between sustainable supply chain management, stakeholder pressure, and corporate sustainability performance," Journal of Business ethics, vol. 119, no. 3, pp. 317-328, 2014.

[38] S. B. Banerjee, "Who sustains whose development? Sustainable development and the reinvention of nature," Organization Studies, vol. 24, no. 1, pp. 143-180, 2003.

[39] T. M. Hult, D. J. Ketchen, G. L. Adams, and J. A. Mena, "Supply chain orientation and balanced scorecard performance," Journal of Managerial Issues, vol. 20, no. 4, pp. 526$544,2008$. 
[40] J. C. Narver and S. F. Slater, "The effect of a market orientaion on business profitability," Journal of Marketing, pp. 20-35, Oct. 1990.

[41] S. C T, D. H. J, and S. B, "Shehzad, C. T., de Haan, J., \& Scholtens, B. (2010). The impact of bank ownership concentration on impaired loans and capital adequacy. Journal of Banking and Finance, 34(2), 399-408.," 2010.

[42] R. E. Freeman and R. A. Phillips, "Stakeholder theory: A libertarian defense," Business Ethics Quarterly, vol. 12, no. 3, pp. 331-350, 2002.

[43] T. Donaldson and L. E. Preston, "Stakeholder theory of the corporation: concepts, evidence, and implications," Academy of Management, vol. 20, no. 1, pp. 65-91, 1995.

[44] T. Donaldson and L. E. Preston, "Stakeholder management and organizational wealth," Academy of Management Review, vol. 24, pp. 619-620, 1999.

[45] T. M. Jones, "Instrumental stakeholder theory: A synthesis of ethics and economics," The Academy of Management Review, vol. 20, no. 2, pp. 404-437, 1995.

[46] J. Frooman, "Stakeholder influence strategies. TheAcademy of," Management Review, vol. 24, no. 2, pp. 191-205, 1999.

[47] T. McDowell, "Fun at work: scale development, confirmatory factor analysis, and links to organizational outcomes", Doctoral dissertation, Alliant International, vol. 65. University, Alhambra, CA: Dissertation Abstracts International, 2004.

[48] A. J. Hillman and G. D. Keim, "Stakeholder value, stake holder management, and social issues: what's the bottom line?," Strategic Management Journal, vol. 22, no. 2, pp. 125139, 2001.

[49] J. E. Dutton, D. J.M., and H. C.V, "Organizational images and member identifications," Administrative Science Quarterly, vol. 39, pp. 239-263, 1994.

[50] M. J. Maloni and M. E. Brown, "Corporate social responsibility in the supply chain: An application in the food industry," Journal of Business Ethics, vol. 68, no. 1, pp. 35-52, 2006.

[51] J. H. Dyer and H. Singh, "The relational view: cooperative strategy and sources of interorganizational competitive advantage," Academy of Management Review, vol. 23, pp. 660-679, 1998.

[52] C. J. Fombrun, Reputation: Realizing Value from the Corporate Image. Boston, MA: Harvard Business School Press, 1996.

[53] J. Sarkis, P. Gonzales-Torre, and B. Adenso-Diaz, "Stakeholder pressure and the adoption of environmental practices: The mediating effect of training," Journal of Operations Management, vol. 28, no. 2, pp. 163-176, 2010.

[54] M. A. Hitt, D. Ireland, and H. R. E, Strategic Management Competitiveness and Globalization. Concepts, Ninth Edition, South-Western-Cengage Learning, USA, 2011.

[55] D. G. Sirmon, M. A. Hitt, and R. D. Ireland, "Managing firm resources in dynamic enviornments to create value: Looking inside the blackbox," Academy of Management Review, vol. 32, no. 1, pp. 273-292, 2007.

[56] B. Squire, P. D. Cousins, B. Lawson, and S. Brown, "The effect of supplier supplier manufactureing capabilities on buyer responsiveness," International Journal of Operation production management, vol. 29, no. 8, pp. 766-788., 2009.

[57] M. A. Peteraf, "The cornerstones of competitive advantage: a resource-based view," Strategic Management, vol. 14, no. 3, pp. 179-91, 1993.

[58] D. G. Hoopes, T. L. Madsen, and G. Walker, "Guest Guest editors' introduction to the special issue: why is there a resource-based view? Toward a theory of competitive heterogeneity," Strategic Management Journal, vol. 24, pp. 889-902, 2003. 
[59] J. B. Barney and P. M. and Wright, "On becoming a strategic partner: the role ofhuman resources in gaining competitive advantage," Human Resource Manage-ment, vol. 37, no. 1, pp. 31-46, 1998.

[60] W. S. DeSarbo, C. A. Di Benedetto, and M. Song, "Heterogeneous resource based view for exploring relationships between firm performance and capabilities," Journal of Modelling in Marketing, vol. 2, no. 2, pp. 103-130, 2007.

[61] C. C. Defee and B. S. Fugate, "Changing perspectives of capabilities in the dynamic supply chain era," International Journal of Logistic Management, vol. 21, no. 2, pp. 180-206, 2010.

[62] P. Beske, "Dynamic capabilities and sustainable supply chain management," International Journal of Physical Distribution Logistic Management, vol. 42, no. 2, pp. 372-387, 2012.

[63] P. Beske, A. Land, and S. Seuring, "Sustainable supply chain management practices and dynamic capabilities in the food industry: a critical analysis of the literature," International Journal of Production Economics, vol. 152, no. 2, pp. 131-143, 2014.

[64] I. Chen and S. Chen, Corporate Governance and Investment Efficiency of Diversified firms: Evidence from Corporate Asset Purchases. 2013.

[65] B. Simamora, Analisis Multivariat Pemasaran. Jakarta (ID: PT Gramedia Pustaka Utama, 2005.

[66] J. Gonzales-Benito, "The effect of manufacturing pro-activity on environmental management: An exploratory analysis," International Journal of Production Research, vol. 46, no. 24, pp. 7017-7038, 2008.

[67] J. Pfeffer and G. R. salancik, "The esternal control of organizations: A resource dependence perspective," Standford University, Standford, 1978.

[68] G. Kassinis and N. Vafeas, "Stakeholder pressures and environmental performance," Academy of Management Journal, vol. 49, no. 1, pp. 145-159, 2006.

[69] R. Daft and K. E. Weick, "Toward a model of organizations as interpretative systems," Academy of Management Review, vol. 9, pp. 284-295, 1984.

[70] M. Delmas, "Stakeholders and competitive advantage: The case for ISO 14001. Production and," Operations Management, vol. 10, no. 3, pp. 343-358, 2001.

[71] C. Reuter, K. Foerstl, E. Hartmann, and C. Blome, "Sustainable global supplier management: The role of dynamic capabilities in achieving competitive advantage," Journal of Supply Chain Management: A Global Review of Purchasing \& Supply, vol. 46, no. 2, pp. 45-63, 2010.

[72] C. R. Carter, "Ethical issues in international buyer-supplier relationships: A dyadic examination," Journal of Operations Management, vol. 18, no. 2, pp. 191-208, 2000.

[73] C. R. Carter, "A framework of supply chain management: Moving toward new theory," International Journal of Physical Distribution \& Logistics Management, vol. 38, no. 5, pp. 360-387., 2008.

[74] M. Mueller, V. G. Dos Santos, and S. Seuring, "The contribution of environmental and social standards towards ensuring legitimacy in supply chain governance," Journal of Business Ethics, vol. 59, no. 4, pp. 509-523, 2009.

[75] J. Hong, Y. Zhang, and M. Ding, "Sustainable supply chain management practices, supply chain dynamic capabilities, and enterprise performance," Journal of Cleaner Production, vol. 172, pp. 3508-3519, 2018.

[76] C. E. Helfat and M. A. Peteraf, "The dynamic resource-based view: Capability Lifecycles," Strategic Management Journal Strat. Mgtnt, vol. 24, pp. 991-0, 2003. 
[77] F. Caniato, A. Moretto, and M. Caridi, "Dynamic capabilities for fashion-luxury supply chain innovation," International Journal of Retail and Distribution Management, vol. 41, no. 11/12, pp. 940-960, 2013. 